\title{
Thymoquinone chemosensitizes colon cancer cells through inhibition of NF-אB
}

\author{
LIDA ZHANG, YANGQIU BAI and YUXIU YANG \\ Department of Gastroenterology, The Affiliated Henan Provincial People's Hospital, \\ Zhengzhou University, Zhengzhou, Henan 450003, P.R. China \\ Received January 13, 2015; Accepted February 12, 2016
}

DOI: 10.3892/ol.2016.4971

\begin{abstract}
In the present study, the effects and molecular mechanisms of thymoquinone (TQ) on colon cancer cells were investigated. Cell viability was determined using a Cell Counting Kit-8 assay, and the results revealed that treatment with TQ significantly decreased cell viability in COLO205 and HCT116 cells in a dose-dependent manner. TQ treatment additionally sensitized COLO205 and HCT116 cells to cisplatin therapy in a concentration-dependent manner. To investigate the molecular mechanisms of TQ action, western blot analysis was used to determine the levels of phosphorylated p65 and nuclear factor- $\kappa \mathrm{B}(\mathrm{NF}-\kappa \mathrm{B})$-regulated gene products vascular endothelial growth factor (VEGF), c-Myc and B-cell lymphoma $2(\mathrm{Bcl}-2)$. The results indicated that TQ treatment significantly decreased the level of phosphorylated p65 in the nucleus, which indicated the inhibition of NF- $\mathrm{KB}$ activation by TQ treatment. Treatment with TQ also decreased the expression levels of VEGF, c-Myc and Bcl-2. In addition, the inhibition of NF- $\mathrm{KB}$ activation with a specific inhibitor, pyrrolidine dithiocarbamate, potentiated the induction of cell death and caused a chemosensitization effect of TQ in colon cancer cells. Overall, the results of the present study suggested that TQ induced cell death and chemosensitized colon cancer cells by inhibiting NF- $\mathrm{\kappa B}$ signaling.
\end{abstract}

\section{Introduction}

Cancer is a significant public health problem worldwide. According to the World Cancer Research Fund International, 12.7 million cancer-associated mortalities (13\% of all mortalities) occurred worldwide in 2008 , with males accounting for 6.6 million mortalities and females accounting

Correspondence to: Professor Yuxiu Yang, Department of Gastroenterology, The Affiliated Henan Provincial People's Hospital, Zhengzhou University, 7 Weiwu Road, Zhengzhou, Henan 450003, P.R. China

E-mail: yangyuxiu668@163.com

Key words: thymoquinone, chemosensitization, cell death, nuclear factor- $\mathrm{kB}$, colon cancer for 6 million (1). In developed countries, colorectal cancer is one of the most commonly observed types of cancer, ranking 2nd and 3rd in women and men, respectively (1). The lifetime risk for colorectal cancer development in the general population is $\sim 6 \%$, and colorectal cancer is responsible for $\sim 8 \%$ of all cancer-associated mortalities worldwide (1). Among the Chinese population, the incidence of colorectal cancer is increasing (2). At present, no optimal adjuvant chemotherapy exists for clinical use; therefore, developing rationally designed, novel adjuvant therapeutic tools for the treatment of colon cancer is a constant requirement (2). Previously, the use of natural substances, including curcumin, eicosapentaenoic acid, apple polyphenols, capsaicin and thymoquinone (TQ), for cancer chemoprevention has been investigated (3-5). TQ is the primary active ingredient of volatile Nigella sativa (black cumin) seed oil, which is used as a spice in countries with a low incidence of colorectal cancer, including Egypt, Pakistan and India (6). Traditional medicine has taken advantage of the anti-inflammatory, antioxidant and anticarcinogenic properties associated with TQ, which supports the hypothesis of TQ being a promising dietary chemopreventive agent (6). In the previous decade, the antitumor activity of TQ has been investigated in a number of studies (6-8). TQ was observed to induce antitumor effects in several types of cancer, including breast (9), lung (10), multiple myeloma (11), pancreatic (12), cervical (13), colon (14) and prostate cancer (15), as well as squamous (16) and hepatocellular carcinoma (17), acute lymphoblastic leukemia (18), glioblastoma (19), osteosarcoma (20), neuroblastoma (21), bladder (22), gastric (23) and ovarian cancer (24). Although the effect of TQ has been investigated in numerous types of cancer, the molecular mechanisms underlying its action remain to be elucidated. The present study investigated the effect of TQ on colon cancer cell growth and the underlying molecular mechanisms. In addition, the present study identified the effect and molecular mechanism of TQ action on the chemosensitivity of colon cancer cells to cisplatin (CisPt).

\section{Materials and methods}

Cell culture and materials. TQ, PDTC, Tris, glycine, $\mathrm{NaCl}$, sodium dodecyl sulfate (SDS), bovine serum albumin (BSA) and $\beta$-actin antibody were obtained from Sigma-Aldrich (St. Louis, MO, USA). TQ was dissolved in dimethyl sulfoxide (DMSO; Merck Millipore, Darmstadt, Germany) 
to make a $50 \mathrm{mM}$ stock solution and stored at $-20^{\circ} \mathrm{C}$ until use in subsequent experiments. Additional dilutions were performed in cell culture medium (RPMI-1640; Gibco; Thermo Fisher Scientific, Inc., Waltham, MA, USA) so that the final DMSO concentration was $<0.1 \%$. Primary antibodies, including rabbit polyclonal anti-human p65 (catalog no., sc-101749; 1:500), rabbit polyclonal anti-human B-cell lymphoma 2 (Bcl-2; catalog no., sc-492; 1:2,000), rabbit polyclonal anti-human vascular endothelial growth factor (VEGF; catalog no., sc-507; 1:1,000), mouse polyclonal anti-human c-Myc (catalog no., sc-40: 1:500), and secondary antibodies, including goat anti-rabbit horseradish peroxidase (HRP)-conjugated (catalog no., sc-2054: 1:10,000) and goat anti-mouse HRP-conjugated (catalog no., sc-2005 1:10,000) were obtained from Santa Cruz Biotechnology, Inc. (Dallas, TX, USA). Primary rabbit polyclonal anti-human $\beta$-actin (catalog no., sc-7210: 1:200) antibody was purchased from Sigma-Aldrich. The COLO205 and HCT116 colon cancer cell lines were purchased from American Type Culture Collection (Manassas, VA, USA). The cells were cultured in RPMI-1640 medium (Gibco; Thermo Fisher Scientific, Inc.), supplemented with $10 \%$ heat-inactivated fetal bovine serum (Gibco; Thermo Fisher Scientific, Inc.) and $2 \%$ penicillin/streptomycin (6 mg/ml penicillin, $10 \mathrm{mg} / \mathrm{ml}$ streptomycin; Sigma-Aldrich). The cells were cultured in tissue culture flasks $\left(75 \mathrm{~cm}^{2}\right.$; Corning Incorporated, New York, NY, USA) and incubated at $37^{\circ} \mathrm{C}$ in a humidified chamber containing $5 \% \mathrm{CO}_{2}$.

Cell viability assay. Cell viability was determined using a Cell Counting Kit-8 (CCK-8; Dojindo Laboratories, Kumamoto, Japan). Briefly, $2 \times 10^{4}$ cells per well were seeded into a 96-well plate (Corning Incorporated). Subsequent to $24 \mathrm{~h}$ culturing, cells were treated with cisplatin and TQ for $24 \mathrm{~h}$ or TQ alone for $48 \mathrm{~h}$. Finally, $20 \mu \mathrm{l} \mathrm{CCK-8} \mathrm{solution} \mathrm{was} \mathrm{added} \mathrm{to} \mathrm{each} \mathrm{well,}$ and was incubated for $2 \mathrm{~h}$ at $37^{\circ} \mathrm{C}$. The optical density (OD) of each well at $450 \mathrm{~nm}$ was measured using a VICTOR ${ }^{\text {TM }} \mathrm{X}$ multi-label reader (PerkinElmer, Inc., Waltham, MA, USA). The percentage cell viability was calculated as follows: $\left(\mathrm{OD}_{\text {drug }} / \mathrm{OD}_{\text {control }}\right) \times 100$. To analyze the role of nuclear factor- $\kappa \mathrm{B}$ $(\mathrm{NF}-\kappa \mathrm{B})$ in TQ activity, cells $\left(2 \times 10^{4}\right.$ cells per well) were treated with $50 \mu \mathrm{m}$ pyrrolidine dithiocarbamate (PDTC) in combination with TQ for 12, 24 and $48 \mathrm{~h}$. The percentage cell growth inhibition was calculated as follows: $\left(\mathrm{OD}_{\text {control }}-\mathrm{OD}_{\text {drug }}\right)$ x 100 .

Preparation of nuclear extract. Nuclear extracts were prepared as previously described (25). Briefly, cells were harvested, washed twice with ice-cold phosphate buffered saline (PBS; Hyclone, Beijing, China) for $1 \mathrm{~min}$ and resuspended in $1 \mathrm{ml}$ of ice-cold PBS. Cells were pelleted by centrifugation at $12,000 \mathrm{x}$ g for $5 \mathrm{~min}$, suspended in ice-cold buffer [10 mmol/1 4-(2-hydroxyethyl)-1-piperazineethanesulfonic acid (HEPES), $1.5 \mathrm{mmol} / 1 \mathrm{MgCl}_{2}, 0.2 \mathrm{mmol} / \mathrm{K} \mathrm{KCl}$, $0.2 \mathrm{mmol} / 1$ phenylmethylsulphonyl fluoride, $0.5 \mathrm{mmol} / 1$ dithothreitol], mixed by vortexing for $10 \mathrm{sec}$ and centrifuged at $12,000 \mathrm{x} \mathrm{g}$ for $5 \mathrm{~min}$. The nuclear pellet was washed in $1 \mathrm{ml}$ buffer $(20 \mathrm{mmol} / 1 \mathrm{HEPES}, 25 \%$ glycerol, $0.42 \mathrm{~mol} / \mathrm{l} \mathrm{NaCl}$, $1.5 \mathrm{mmol} / 1 \mathrm{MgCl}_{2}, 0.2 \mathrm{mmol} / 1$ ethylenediaminetetraacetic acid), resuspended in $30 \mathrm{ml}$ buffer, mixed by rotation for $30 \mathrm{~min}$ at $4^{\circ} \mathrm{C}$ and centrifuged at $12,000 \mathrm{x} \mathrm{g}$ for $20 \mathrm{~min}$. Finally, the supernatants were used as nuclear extracts.

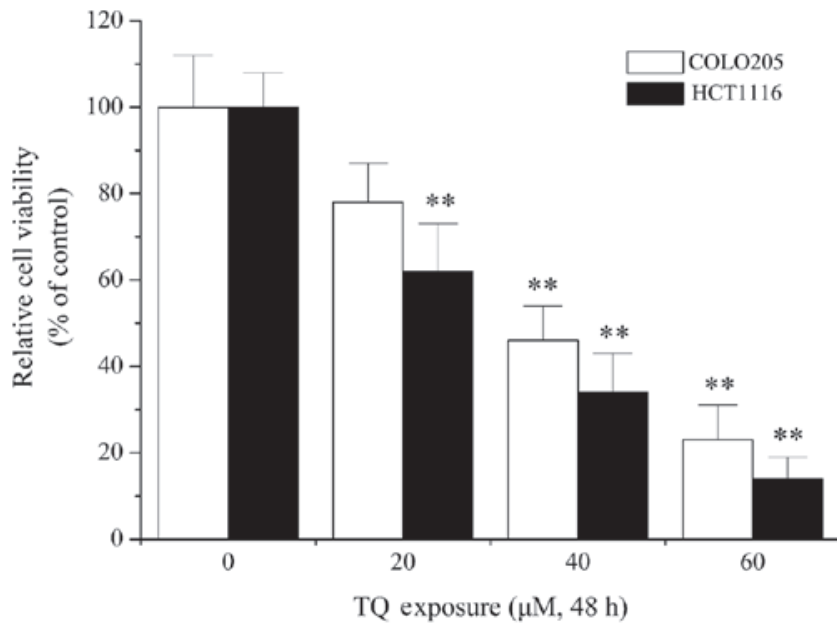

Figure 1. TQ induced death of colon cancer cells. Cultured cells $\left(2 \times 10^{4}\right.$ cells per well) were treated with various concentrations $(0,20,40$ and $60 \mu \mathrm{M})$ of TQ for 48 h. Cell viability was measured using Cell Counting Kit- 8 and presented as a percentage of the control. Data are presented as the mean \pm standard deviation of five experiments. ${ }^{* *} \mathrm{P}<0.05$ vs. the respective control group. TQ, thymoquinone.

Western blot analysis. Using 12\% SDS-polyacrylamide gel electrophoresis (SDS-PAGE), whole cell lysates or nuclear extracts were electrophoresed, as previously described (26). The proteins were transferred onto a $0.4-\mu \mathrm{m}$ polyvinylidene difluoride membrane (EMD Millipore, Bedford, MA, USA) in transfer buffer $(25 \mathrm{mM}$ Tris, $\mathrm{pH} 8.5,0.2 \mathrm{M}$ glycine and $20 \%$ methanol). The membranes were blocked by $5 \%$ BSA in Tris-buffered saline containing 0.1\% Tween-20 (TBST) for $1 \mathrm{~h}$, washed twice with TBST for $10 \mathrm{~min}$ each and incubated with primary $\beta$-actin, p65, Bcl-2, VEGF and c-Myc antibodies at $4^{\circ} \mathrm{C}$ overnight. Subsequent to three washes with TBST for $10 \mathrm{~min}$ each, the membranes were probed with secondary peroxidase-conjugated antibody (dilution, 1:10,000; Sigma-Aldrich). Finally, the immunoreactive bands were visualized using an enhanced chemiluminescence detection kit (Immobilon WBKLS0500; Merck Millipore). $\beta$-actin was used as an internal control for all western blot analyses.

Statistical analysis. SPSS version 17.0 software (SPSS Inc., Chicago, IL, USA) was used for statistical analysis. Values were expressed as the mean \pm standard deviation. Numeric variables were compared by one-way analysis of variance. $\mathrm{P}<0.05$ was considered to indicate a statistically significant difference.

\section{Results}

Effect of $T Q$ on the viability of colon cancer cells. Previous studies have shown the antitumor and anticarcinogenic activities of TQ in numerous types of cancer, including breast cancer, glioblastoma and lymphoma (27-29). In order to elucidate the molecular mechanisms underlying the function of TQ, the effect of TQ on colon cancer cells was examined in the present study. As shown in Fig. 1, 20 $\mu \mathrm{M}$ TQ treatment resulted in a significant decrease in cell viability in HCT1116 cells when compared with the control $(\mathrm{P}=0.013)$. Furthermore, $40 \mu \mathrm{M}$ TQ treatment significantly 
A

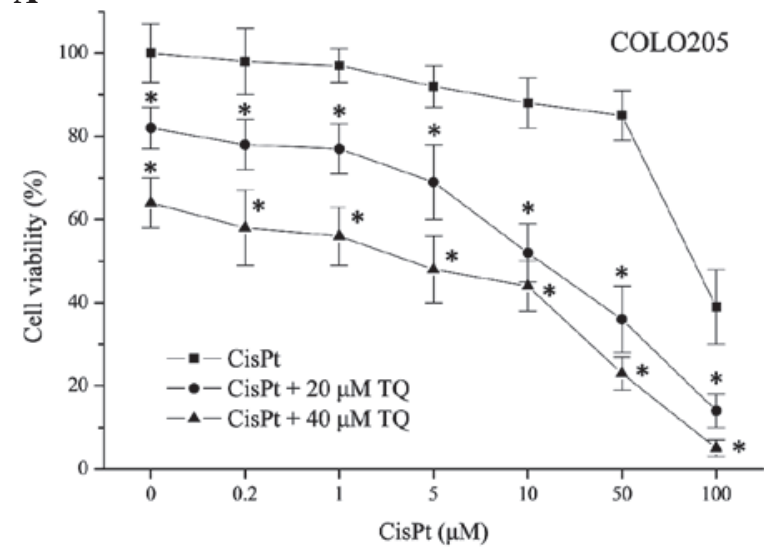

B

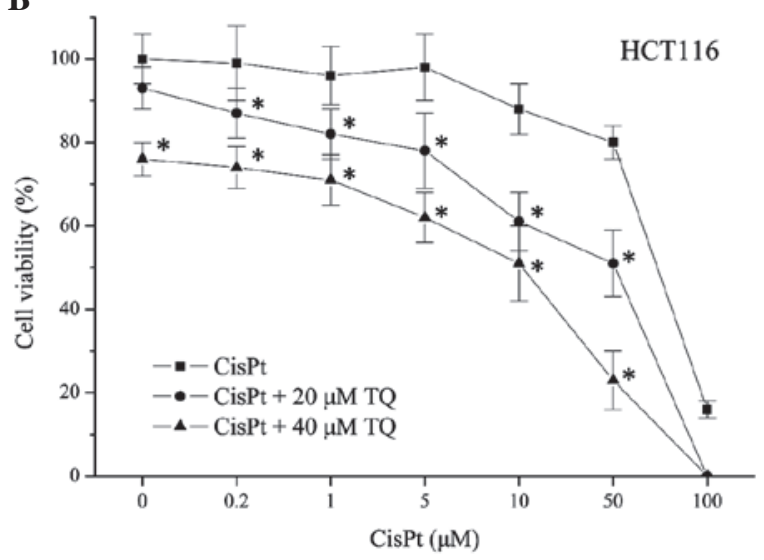

Figure 2. TQ increases the cytotoxicity of CisPt in colon cancer cells. (A) COLO205 cell line; (B) HCT116 cell line. Colon cancer cells were treated with 0.2 , $1,5,10,50$ and $100 \mu \mathrm{M}$ CisPt, with or without 20 or $40 \mu \mathrm{M}$ TQ for $24 \mathrm{~h}$. Cell viability was measured by a Cell Counting Kit- 8 and is presented as a percentage of the control. Values are expressed as the mean \pm standard deviation of five experiments. ${ }^{*}<0.05$ vs. cisplatin alone. TQ, thymoquinone; CisPt, cisplatin.

A

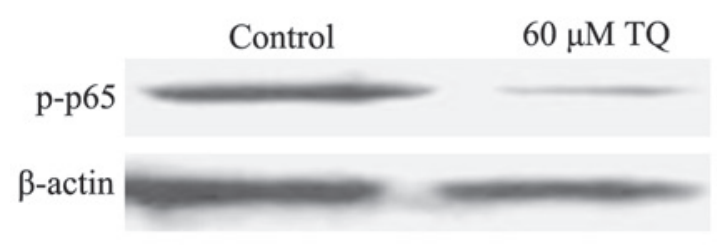
$65 \mathrm{kDa}$ $42 \mathrm{kDa}$
B

VEGF
c-Myc
Bcl-2

Control

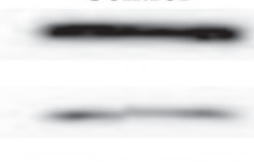

$\beta$-actin
$60 \mu \mathrm{M}$ TQ

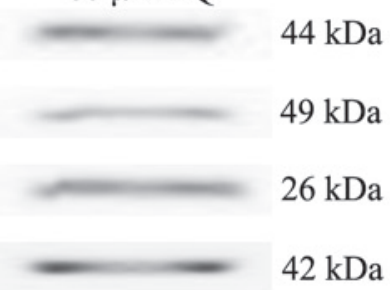

Figure 3. TQ inhibits the activation of $\mathrm{NF}-\kappa \mathrm{B}$ and downregulates its downstream gene expression. (A) TQ inhibited phosphorylation of the subunit of NF- $\mathrm{B}$, p65. COLO205 cells were treated with $60 \mu \mathrm{M}$ TQ for $18 \mathrm{~h}$. Cells were harvested and the expression of phosphorylated p65 in the nucleus was evaluated by western blot analysis. $\beta$-actin was used as an internal control. A representative blot of three experiments with similar results is shown. (B) TQ downregulated $\mathrm{NF}-\kappa \mathrm{B}$ downstream gene products in COLO205 cells. Following $18 \mathrm{~h}$ of incubation, the levels of VEGF, c-Myc and Bcl-2 were determined by western blot analysis. $\beta$-actin was used as an internal control. A representative blot of three experiments with similar results is shown. TQ, thymoquinone; NF- $\kappa \mathrm{B}$, nuclear factor- $\kappa \mathrm{B}$; VEGF, vascular endothelial growth factor; Bcl-2, B-cell lymphoma 2.

decreased call viability in COLO205 cells compared with the control $(\mathrm{P}=0.007)$. Cytotoxicity assays indicated that TQ dose-dependently decreased cell viability of the COLO205 and HCT116 colon cancer cell lines (Fig. 1), which confirmed the antitumor activity of TQ, as previously reported (30,31).

$T Q$ chemosensitizes colon cancer cells. The present study aimed to investigate whether TQ affected the sensitivity of colon cancer cells to chemotherapy. Therefore, TQ and CisPt were combined to treat COLO205 and HCT116 colon cancer cell lines. As shown in Fig. 2, treatment with cisplatin alone induced COLO205 and HCT1116 cell death in a dose-dependent manner. Combined treatment with cisplatin $(0.2 \mu \mathrm{M})$ and TQ (20 or $40 \mu \mathrm{M})$ significantly decreased the cell viability of COLO205 ( $\mathrm{P}=0.021,20 \mu \mathrm{M}$ TQ; $\mathrm{P}=0.003,40 \mu \mathrm{M}$ TQ) and HCT116 cells $(\mathrm{P}=0.038,20 \mu \mathrm{M}$ TQ; $\mathrm{P}=0.004,40 \mu \mathrm{M}$ TQ) when compared with $0.2 \mu \mathrm{M}$ cisplatin treatment alone. These results revealed that cell death induced by CisPt was enhanced by TQ in a concentration-dependent manner (Fig. 2), which indicated that TQ may potentiate the chemosensitivity of colon cancer cells.

Role of $N F-\kappa B$ in TQ activity. As demonstrated in the present results, TQ treatment may result in cell death and chemosensitizing of colon cancer cells. Therefore, the present study aimed to investigate the underlying mechanisms of TQ action, including the role of $\mathrm{NF}-\kappa \mathrm{B}$ in the process. Western blot analysis was used to determine the effect of TQ on $\mathrm{NF}-\kappa \mathrm{B}$ activation. The results demonstrated that $60 \mu \mathrm{M}$ TQ significantly inhibited the phosphorylation of $\mathrm{p} 65$ protein, subunit of NF- $\mathrm{B}$ (Fig. 3A). Furthermore, the expression levels of NF- $\kappa \mathrm{B}$-regulated genes that are involved in tumor angiogenesis, survival and apoptosis were measured. As demonstrated in Fig. 3B, protein levels of VEGF, c-Myc and Bcl-2 were markedly downregulated following $60 \mu \mathrm{M}$ TQ treatment.

$N F-\kappa B$ inhibitor, PDTC, potentiates the activity of $T Q$. As TQ inhibited NF- $\kappa \mathrm{B}$ activation, the effect of $\mathrm{NF}-\kappa \mathrm{B}$ on TQ function was assessed. The NF- $\kappa \mathrm{B}$ inhibitor, PDTC, was used to investigate the activity of TQ. As demonstrated in Fig. 4, combined treatment with $10 \mu \mathrm{M}$ cisplatin and $40 \mu \mathrm{M}$ TQ treatment for 24 or $48 \mathrm{~h}$ significantly inhibited cell growth inhibition when compared with $40 \mu \mathrm{M}$ TQ treatment alone ( $\mathrm{P}=0.018$ and $\mathrm{P}=0.009$, respectively) in COLO205 cells. Treatment with $50 \mu \mathrm{M}$ PDTC further potentiated the growth inhibition observed following $24 \mathrm{~h}(\mathrm{P}=0.002)$ and $48 \mathrm{~h}$ $(\mathrm{P}=0.031)$ treatment when compared with $10 \mu \mathrm{M}$ cisplatin and $40 \mu \mathrm{M}$ TQ combined treatment. For HCT1116 cells, following 12,24 and $48 \mathrm{~h}$ treatment with $50 \mu \mathrm{M}$ PDTC, $10 \mu \mathrm{M}$ cisplatin and $40 \mu \mathrm{M}$ TQ significantly inhibited cell growth inhibition 

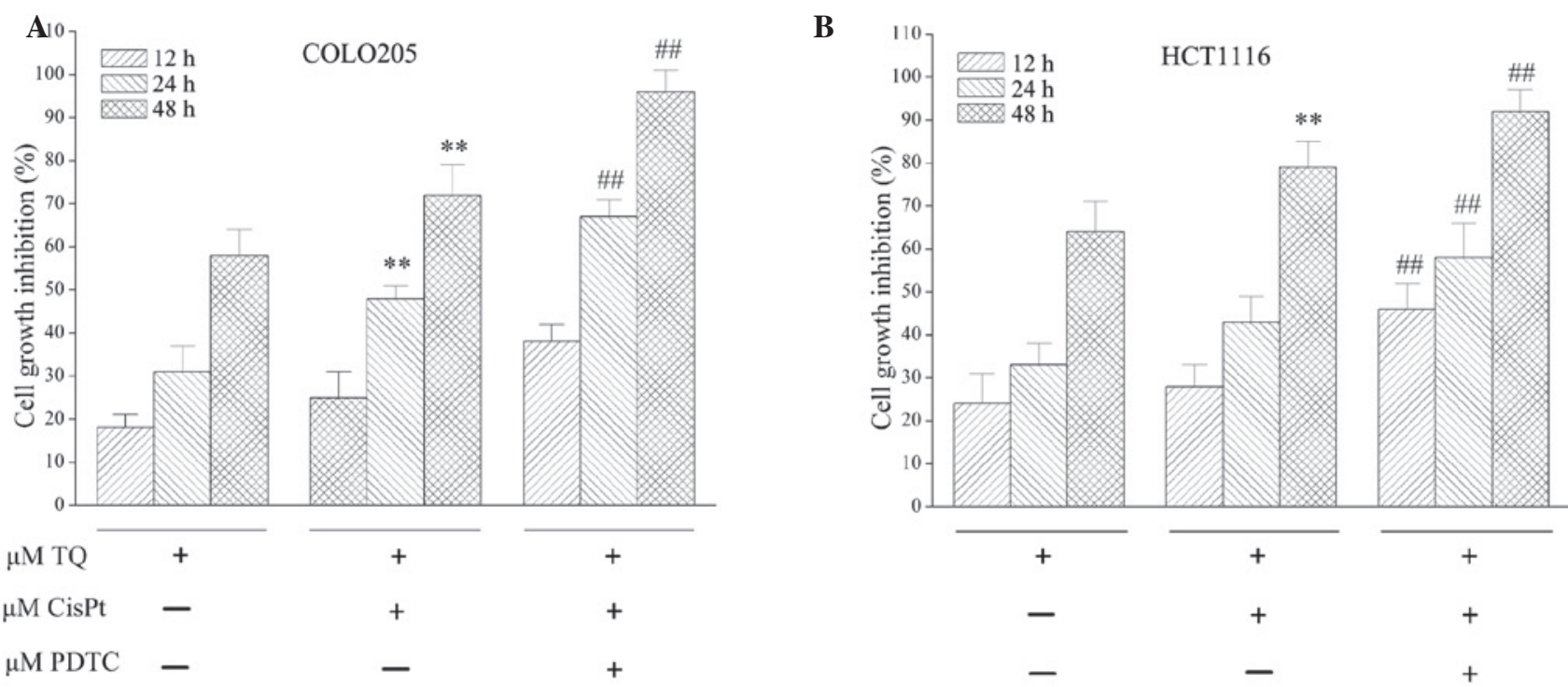

Figure 4. PDTC, a nuclear factor- $\mathrm{KB}$ inhibitor, potentiated the death-inducing effect of TQ on colon cancer cells. (A) COLO205 cell line; (B) HCT116 cell line. Cultured cells were seeded in a 96-well plate at a density of $2 \times 10^{4}$ cells per well and treated with $40 \mu \mathrm{M} \mathrm{TQ}$, with or without $50 \mu \mathrm{M}$ PDTC. Following 12,24 or $48 \mathrm{~h}$ incubation, cell viability was determined with a Cell Counting Kit-8. Cell viability is presented as a percentage of the control. Results are presented as the mean \pm standard deviation of at least three independent experiments. ${ }^{* *} \mathrm{P}<0.05$ vs. TQ treatment; ${ }^{\# \#} \mathrm{P}<0.05$ vs. TQ+CisPt treatment. TQ, thymoquinone; PDTC, pyrrolidine dithiocarbamate; CisPt, cisplatin.

$(\mathrm{P}=0.014, \mathrm{P}=0.043$ and $\mathrm{P}=0.027$, respectively) when compared with combined $10 \mu \mathrm{M}$ cisplatin and $40 \mu \mathrm{M}$ TQ treatment. Furthermore, a chemosensitization effect of TQ on colon cancer cells was enhanced by $50 \mu \mathrm{M}$ PDTC treatment, which was demonstrated by increased cell growth inhibition (Fig. 4).

\section{Discussion}

Nigella sativa is an annual herbaceous plant belonging to the Ranunculaceae family, which has been commonly used in traditional Middle Eastern folk medicine as a natural remedy for various ailments for $>2,000$ years (8). Nigella sativa is additionally used as a food additive and flavoring in numerous countries (8). TQ, or 2-isopropyl-5-methyl-1,4-benzoquinone, is a Nigella sativa essential oil that is known to be the principal active compound of the seed, and is responsible for a number of its antioxidant and anti-inflammatory effects $(6,8)$.

In 2003, Shoieb et al (32) reported in vitro experimental results that revealed TQ was able to inhibit growth and induce apoptosis in cancer cell lines. Since then, increasing numbers of studies have focused on TQ in cancer therapy. Numerous in vitro and in vivo studies have investigated the antitumor activity of TQ in several types of cancer $(6,14,19,27-29,33)$. In tumor protein p53-null myeloblastic leukemia HL-60 cells, TQ induced apoptosis through an intrinsic signaling pathway (34). In human multiple myeloma cells, TQ inhibits proliferation, induces apoptosis and exerts a chemosensitization effect through suppressing signal transducer and activator of transcription 3 (acute-phase response factor) activation (35), and decreases F-actin polymerization and $\mathrm{Bcl}-2 / \mathrm{Bcl}-2$ like 1 expression (36). TQ-induced apoptosis has been indicated to be mediated by reactive oxygen species generation $(29,33,37)$ and the mitogen-activated protein kinase 14 signaling pathway (33). In 2004, Gali-Muhtasib et al (38) reported that TQ triggered apoptotic cell death in human colorectal cancer cells via a p53-dependent mechanism, and in 2008, Gali-Muhtasib et al (31) demonstrated that TQ triggered inactivation of the stress response pathway sensor checkpoint kinase 1 and contributed to apoptosis in colorectal cancer cells. Gali-Muhtasib et al (30) additionally indicated that TQ may inhibit colon tumor cell invasion (30), which was confirmed by additional studies (39-41).

A recent study reported that TQ exerted an antitumor effect through the interruption of pro-survival mitogen-activated protein kinase kinase 7-mitogen-activated protein kinase 1 signaling in colorectal cancer (14). TQ exerted a direct antitumor effect, and also sensitized cancer cells to other therapies $(23,42-44)$. In general, cancer cells may be initially susceptible to chemotherapy; however, over time they may develop resistance through certain mechanisms, including DNA mutations and metabolic changes that promote drug inhibition and degradation. Drug resistance has been a challenge for clinical cancer treatment (45). Velho-Pereira et al (42) reported that TQ may radiosensitize human breast carcinoma cells. Jafri et al (43) indicated that in lung cancer, TQ treatment may overcome resistance and sensitize lung cancer cells to CisPt. Previous studies have revealed the chemosensitization and radiosensitization effect of TQ in pancreatic (44), lung (43), gastric (23) and breast cancer (42). However, the mechanism by which TQ affects the sensitivity of colon cancer to chemotherapy has not been investigated. In the present study, the results confirmed the antitumor activity of TQ in colon cancer cells and provided novel evidence that TQ sensitizes colon cancer cells to CisPt by suppressing NF- $\kappa \mathrm{B}$ activation.

$\mathrm{NF}-\kappa \mathrm{B}$ is an ubiquitous transcription factor, consisting of p50, p65 and nuclear factor- $\kappa \mathrm{B}$ inhibitor $\alpha(\mathrm{I} \kappa \mathrm{B} \alpha)$, which is present in the cytoplasm and is activated in response to certain inflammatory stimuli, environmental pollutants, prooxidants, carcinogens, stress and growth factors (46). Following activation, NF- $\kappa \mathrm{B}$ translocates from the cytoplasm to the nucleus, binds DNA and induces gene transcription. A number of kinases have been associated with the activation of $N F-\kappa B$, including I $\kappa \mathrm{B} \alpha$ kinase. This activation has been shown to 
result in the expression of a number of gene products that regulate apoptosis, proliferation, chemoresistance, radioresistance, invasion, angiogenesis, metastasis and inflammation $(47,48)$. In numerous human cancers $\mathrm{NF}-\kappa \mathrm{B}$ is constitutively activated (49-51). NF- $\kappa \mathrm{B}$ activation has been associated with various aspects of oncogenesis, including control of apoptosis, cell cycle, differentiation and cell migration $(52,53)$. In addition, the activation of NF- $\mathrm{KB}$ in cancer cells by chemotherapy or radiation may hinder the ability of cancer therapy to induce cell death; therefore, $\mathrm{NF}-\kappa \mathrm{B}$ has been used as a target for tumor therapies $(52,53)$. In colon cancer, via the regulation of numerous genes differentially expressed and implicated in tumorigenesis, $\mathrm{NF}-\kappa \mathrm{B}$ activation participates in the promotion and progression steps of colon cancer (54). The present study investigated the effect of TQ on NF- $\kappa \mathrm{B}$ activation, and additionally examined the effect of TQ on $N F-\kappa B$-regulated gene products. The results of the present study revealed that TQ treatment inhibited the phosphorylation of p65 protein in the nucleus of colon cancer cells and decreased the expression of NF- $\kappa \mathrm{B}$-regulated genes, including VEGF, c-Myc and Bcl-2. In addition, the inhibition of $\mathrm{NF}-\kappa \mathrm{B}$ with a specific inhibitor, PDTC, may potentiate the cell death induction and chemosensitization effect of TQ in colon cancer cells.

In conclusion, the present study demonstrated that TQ may result in cell death in colon cancer cells and sensitize colon cancer cells to CisPt therapy by suppressing NF- $\kappa \mathrm{B}$ activation. TQ may be a positive option for adjuvant chemotherapy in the treatment of colon cancer.

\section{References}

1. Ferlay J, Shin HR, Bray F, Forman D, Mathers C and Parkin DM: Estimates of worldwide burden of cancer in 2008: GLOBOCAN 2008. Int J Cancer 127: 2893-2917, 2010.

2. Jin P, Wu ZT, Li SR, Li SJ, Wang JH, Wang ZH, Lu JG, Cui XJ, Han Y, Rao J and Sheng JQ: Colorectal cancer screening with fecal occult blood test: A 22-year cohort study. Oncol Lett 6: $576-582,2013$

3. Kim B and Giardiello FM: Chemoprevention in familial adenomatous polyposis. Best Pract Res Clin Gastroenterol 25: 607-622, 2011.

4. Fini L, Piazzi G, Daoud Y, Selgrad M, Maegawa S, Garcia M, Fogliano V, Romano M, Graziani G, Vitaglione P, et al: Chemoprevention of intestinal polyps in ApcMin/+ mice fed with western or balanced diets by drinking annurca apple polyphenol extract. Cancer Prev Res (Phila) 4: 907-915, 2011.

5. Rajput $\mathrm{S}$ and Mandal M: Antitumor promoting potential of selected phytochemicals derived from spices: A review. Eur J Cancer Prev 21: 205-215, 2012.

6. Woo CC, Kumar AP, Sethi G and Tan KH: Thymoquinone: Potential cure for inflammatory disorders and cancer. Biochem Pharmacol 83: 443-451, 2012.

7. Abukhader MM: Thymoquinone in the clinical treatment of cancer: Fact or fiction? Pharmacogn Rev 7: 117-120, 2013.

8. Schneider-Stock R, Fakhoury IH, Zaki AM, El-Baba CO and Gali-Muhtasib HU: Thymoquinone: Fifty years of success in the battle against cancer models. Drug Discov Today 19: 18-30, 2014.

9. Sutton KM, Greenshields AL and Hoskin DW: Thymoquinone, a bioactive component of black caraway seeds, causes G1 phase cell cycle arrest and apoptosis in triple-negative breast cancer cells with mutant p53. Nutr Cancer 66: 408-418, 2014.

10. Yang J, Kuang XR, Lv PT and Yan XX: Thymoquinone inhibits proliferation and invasion of human nonsmall-cell lung cancer cells via ERK pathway. Tumour Biol 36: 259-269, 2015

11. Siveen KS, Mustafa N, Li F, Kannaiyan R, Ahn KS, Kumar AP, Chng WJ and Sethi G: Thymoquinone overcomes chemoresistance and enhances the anticancer effects of bortezomib through abrogation of $\mathrm{NF}-\kappa \mathrm{B}$ regulated gene products in multiple myeloma xenograft mouse model. Oncotarget 5: 634-648, 2014.
12. Mu GG, Zhang LL, Li HY, Liao Y and Yu HG: Thymoquinone pretreatment overcomes the insensitivity and potentiates the antitumor effect of gemcitabine through abrogation of Notch1, $\mathrm{PI} 3 \mathrm{~K} / \mathrm{Akt} / \mathrm{mTOR}$ regulated signaling pathways in pancreatic cancer. Dig Dis Sci 60: 1067-1080, 2015.

13. Ichwan SJ, Al-Ani IM, Bilal HG, Suriyah WH, Taher M and Ikeda MA: Apoptotic activities of thymoquinone, an active ingredient of black seed (Nigella sativa), in cervical cancer cell lines. Chin J Physiol 57: 249-255, 2014.

14. El-Baba C, Mahadevan V, Fahlbusch FB, S SM, Rau TT, Gali-Muhtasib $\mathrm{H}$ and Schneider-Stock R: Thymoquinone-induced conformational changes of PAK1 interrupt prosurvival MEK-ERK signaling in colorectal cancer. Mol Cancer 13: 201, 2014.

15. Dirican A, Atmaca H, Bozkurt E, Erten C, Karaca B and Uslu R: Novel combination of docetaxel and thymoquinone induces synergistic cytotoxicity and apoptosis in DU-145 human prostate cancer cells by modulating PI3K-AKT pathway. Clin Transl Oncol 17: 145-151, 2015.

16. Chu SC, Hsieh YS, Yu CC, Lai YY and Chen PN: Thymoquinone induces cell death in human squamous carcinoma cells via caspase activation-dependent apoptosis and LC3-II activation-dependent autophagy. PLoS One 9: e101579, 2014.

17. Ashour AE, Abd-Allah AR, Korashy HM, Attia SM, Alzahrani AZ, Saquib Q, Bakheet SA, Abdel-Hamied HE, Jamal S and Rishi AK: Thymoquinone suppression of the human hepatocellular carcinoma cell growth involves inhibition of IL-8 expression, elevated levels of TRAIL receptors, oxidative stress and apoptosis. Mol Cell Biochem 389: 85-98, 2014.

18. Salim LZ, Mohan S, Othman R, Abdelwahab SI, Kamalidehghan B, Sheikh BY and Ibrahim MY: Thymoquinone induces mitochondria-mediated apoptosis in acute lymphoblastic leukaemia in vitro. Molecules 18: 11219-11240, 2013.

19. Racoma IO, Meisen WH, Wang QE, Kaur B and Wani AA: Thymoquinone inhibits autophagy and induces cathepsin-mediated, caspase-independent cell death in glioblastoma cells. PLoS One 8: e72882, 2013.

20. Peng L, Liu A, Shen Y, Xu HZ, Yang SZ, Ying XZ, Liao W, Liu HX, Lin ZQ, Chen QY, et al: Antitumor and anti-angiogenesis effects of thymoquinone on osteosarcoma through the NF-кB pathway. Oncol Rep 29: 571-578, 2013.

21. Paramasivam A, Sambantham S, Shabnam J, et al: Anti-cancer effects of thymoquinone in mouse neuroblastoma (Neuro-2a) cells through caspase-3 activation with down-regulation of XIAP. Toxicol Lett 213: 151-159, 2012.

22. Mu HQ, Yang S, Wang YJ and Chen YH: Role of NF- $\kappa B$ in the anti-tumor effect of thymoquinone on bladder cancer. Zhonghua Yi Xue Za Zhi 92: 392-396, 2012 (In Chinese).

23. Lei X, Lv X, Liu M, Yang Z, Ji M, Guo X and Dong W: Thymoquinone inhibits growth and augments 5-fluorouracil-induced apoptosis in gastric cancer cells both in vitro and in vivo. Biochem Biophys Res Commun 417: 864-868, 2012.

24. Nessa MU, Beale P, Chan C, Yu JQ and Huq F: Synergism from combinations of cisplatin and oxaliplatin with quercetin and thymoquinone in human ovarian tumour models. Anticancer Res 31: 3789-3797, 2011.

25. Luo P, Tan Z, Zhang Z, Li H and Mo Z: Inhibitory effects of salvianolic acid $B$ on the high glucose-induced mesangial proliferation via NF- $\kappa \mathrm{B}$-dependent pathway. Biol Pharm Bull 31: 1381-1386, 2008.

26. Lui VW, Boehm AL, Koppikar P, Leeman RJ, Johnson D, Ogagan M, Childs E,Freilino Mand Grandis JR: Antiproliferative mechanisms of a transcription factor decoy targeting signal transducer and activator of transcription (STAT) 3: The role of STAT1. Mol Pharmacol 71: 1435-1443, 2007.

27. Rajput S, Kumar BN, Sarkar S, Das S, Azab B, Santhekadur PK, Das SK, Emdad L, Sarkar D, Fisher PB and Mandal M: Targeted apoptotic effects of thymoquinone and tamoxifen on XIAP mediated Akt regulation in breast cancer. PLoS One 8: e61342, 2013.

28. Kolli-Bouhafs K, Boukhari A, Abusnina A, Velot E, Gies JP, Lugnier $\mathrm{C}$ and Rondé P: Thymoquinone reduces migration and invasion of human glioblastoma cells associated with FAK, MMP-2 and MMP-9 down-regulation. Invest New Drugs 30: 2121-2131, 2012.

29. Hussain AR, Ahmed M, Ahmed S, Manogaran P, Platanias LC, Alvi SN, Al-Kuraya KS and Uddin S: Thymoquinone suppresses growth and induces apoptosis via generation of reactive oxygen species in primary effusion lymphoma. Free Radic Biol Med 50: 978-987, 2011. 
30. Gali-Muhtasib H, Ocker M, Kuester D, Krueger S, El-Hajj Z, Diestel A, Evert M, El-Najjar N, Peters B, Jurjus A, et al: Thymoquinone reduces mouse colon tumor cell invasion and inhibits tumor growth in murine colon cancer models. J Cell Mol Med 12: 330-342, 2008

31. Gali-Muhtasib H, Kuester D, Mawrin C, Bajbouj K, Diestel A, Ocker M, Habold C, Foltzer-Jourdainne C, Schoenfeld P, Peters B, et al: Thymoquinone triggers inactivation of the stress response pathway sensor CHEK1 and contributes to apoptosis in colorectal cancer cells. Cancer Res 68: 5609-5618, 2008.

32. Shoieb AM, Elgayyar M, Dudrick PS, Bell JL and Tithof PK: In vitro inhibition of growth and induction of apoptosis in cancer cell lines by thymoquinone. Int J Oncol 22: 107-113, 2003.

33. Woo CC, Hsu A, Kumar AP, Sethi G and Tan KH: Thymoquinone inhibits tumor growth and induces apoptosis in a breast cancer xenograft mouse model: The role of p38 MAPK and ROS. PLoS One 8: e75356, 2013.

34. El-Mahdy MA, Zhu Q, Wang QE, Wani G and Wani AA: Thymoquinone induces apoptosis through activation of caspase- 8 and mitochondrial events in p53-null myeloblastic leukemia HL-60 cells. Int J Cancer 117: 409-417, 2005.

35. Li F, Rajendran P and Sethi G: Thymoquinone inhibits proliferation, induces apoptosis and chemosensitizes human multiple myeloma cells through suppression of signal transducer and activator of transcription 3 activation pathway. Br J Pharmacol 161: 541-554, 2010.

36. Badr G, Mohany M and Abu-Tarboush F: Thymoquinone decreases F-actin polymerization and the proliferation of human multiple myeloma cells by suppressing STAT3 phosphorylation and Bcl2/Bcl-XL expression. Lipids Health Dis 10: 236, 2011.

37. El-Najjar N, Chatila M, Moukadem H, Vuorela H, Ocker M, Gandesiri M, Schneider-Stock R and Gali-Muhtasib H: Reactive oxygen species mediate thymoquinone-induced apoptosis and activate ERK and JNK signaling. Apoptosis 15: 183-195, 2010

38. Gali-Muhtasib H, Diab-Assaf M, Boltze C, Al-Hmaira J, Hartig R, Roessner A and Schneider-Stock R: Thymoquinone extracted from black seed triggers apoptotic cell death in human colorectal cancer cells via a p53-dependent mechanism. Int J Oncol 25: 857-866, 2004

39. Lang M, Borgmann M, Oberhuber G, Evstatiev R, Jimenez K, Dammann KW, Jambrich M, Khare V, Campregher C, Ristl R and Gasche C: Thymoquinone attenuates tumor growth in ApcMin mice by interference with Wnt-signaling. Mol Cancer 12: 41, 2013.

40. Jrah-Harzallah H, Ben-Hadj-Khalifa S, Almawi WY, Maaloul A, Houas Z and Mahjoub T: Effect of Thymoquinone on 1,2-dimethyl-hydrazine-induced oxidative stress during initiation and promotion of colon carcinogenesis. Eur J Cancer 49: $1127-1135,2013$
41. Asfour W, Almadi S and Haffar L: Thymoquinone suppresses cellular proliferation, inhibits VEGF production and obstructs tumor progression and invasion in the rat model of $\mathrm{DMH}$-induced colon carcinogenesis. Pharmacol Pharm 4: 7-17, 2013.

42. Velho-Pereira R, Kumar A, Pandey BN, Jagtap AG and Mishra KP: Radiosensitization in human breast carcinoma cells by thymoquinone: Role of cell cycle and apoptosis. Cell Biol Int 35: 1025-1029, 2011.

43. Jafri SH, Glass J, Shi R, Zhang S, Prince M and Kleiner-Hancock H: Thymoquinone and cisplatin as a therapeutic combination in lung cancer: In vitro and in vivo. J Exp Clin Cancer Res 29: 87, 2010.

44. Banerjee S, Kaseb AO, Wang Z, Kong D, Mohammad M, Padhye S, Sarkar FH and Mohammad RM: Antitumor activity of gemcitabine and oxaliplatin is augmented by thymoquinone in pancreatic cancer. Cancer Res 69: 5575-5583, 2009.

45. Housman G, Byler S, Heerboth S, Lapinska K, Longacre M, Snyder N and Sarkar S: Drug resistance in cancer: An overview. Cancers (Basel) 6: 1769-1792, 2014.

46. Aggarwal BB: Nuclear factor-kappaB: The enemy within. Cancer Cell 6: 203-208, 2004.

47. Shishodia S and Aggarwal BB: Nuclear factor-kappaB activation mediates cellular transformation, proliferation, invasion angiogenesis and metastasis of cancer. Cancer Treat Res 119: 139-173, 2004.

48. Ahn KS and Aggarwal BB: Transcription factor NF-kappaB: A sensor for smoke and stress signals. Ann NY Acad Sci 1056: 218-233, 2005.

49. Nair A, Venkatraman M, Maliekal TT, Nair B and Karunagaran D: NF-kappaB is constitutively activated in high-grade squamous intraepithelial lesions and squamous cell carcinomas of the human uterine cervix. Oncogene 22: 50-58, 2003.

50. Li W, Tan D, Zenali MJ and Brown RE: Constitutive activation of nuclear factor-kappaB (NF- $\kappa \mathrm{B})$ signaling pathway in fibrolamellar hepatocellular carcinoma. Int J Clin Exp Pathol 3: 238-243, 2009.

51. Nagel D, Vincendeau M, Eitelhuber AC and Krappmann D: Mechanisms and consequences of constitutive NF- $\kappa \mathrm{B}$ activation in B-cell lymphoid malignancies. Oncogene 33: 5655-5665, 2014.

52. Baldwin AS: Control of oncogenesis and cancer therapy resistance by the transcription factor NF-kappaB. J Clin Invest 107: 241-246, 2001.

53. Shen HM and Tergaonkar V: NFkappaB signaling in carcinogenesis and as a potential molecular target for cancer therapy. Apoptosis 14: 348-363, 2009.

54. Wang S, Liu Z, Wang L and Zhang X: NF-kappaB signaling pathway, inflammation and colorectal cancer. Cell Mol Immunol 6: 327-334, 2009. 